\title{
Sexing a sex-role-reversed species based on plumage: potential challenges in the red phalarope
}

Marie-Andrée Giroux, Delphine Ditlecadet, Luc J Martin, Richard B. Lanctot, Nicolas Lecomte

Sex-role reversal, in which males care for offspring, can occur when mate competition is stronger between females than males. Secondary sex traits and mate attracting displays in sex-role-reversed species are usually more pronounced in females than in males. The red phalarope ( Phalaropus fulicarius[i]) is a textbook example of a sex-role-reversed species. It is generally agreed that males are responsible for all incubation and parental care duties, whereas females typically desert males after having completed a clutch and may pair with new males to lay additional clutches. The breeding plumage of female red phalaropes is usually more brightly colored than male plumage, a reversed sexual dichromatism usually associated with sex-role reversal. Here, we confirm with PCR-based sexing that male red phalaropes can exhibit both the red body plumage typical of a female and the incubation behavior typical of a male. Our result, combined with previous observations of brightly colored red phalaropes incubating nests at the same arctic location (Igloolik Island, Nunavut, Canada), suggests that plumage dichromatism alone may not be sufficient to distinguish males from females in this breeding population of red phalaropes. This stresses the need for more systematic genetic sexing combined with standardized description of intersexual differences in red phalarope plumages.

Determining whether such female-like plumage on males is a result of phenotypic plasticity or genetic variation could contribute to further understanding sex-role reversal strategies in the short Arctic summer. 
1 Sexing a sex-role-reversed species based on plumage: potential challenges in the red

2 phalarope

3 Marie-Andrée Giroux ${ }^{1,2,3 *}$, Delphine Ditlecadet ${ }^{4}$, Luc Martin ${ }^{5}$, Richard B. Lanctot ${ }^{6}$, and Nicolas

4 Lecomte ${ }^{1,3,5,7}$

$5{ }^{1}$ Canada Research Chair in Polar and Boreal Ecology, Université de Moncton, E1A 3E9 Canada

$6 \quad{ }^{2}$ Canada Research Chair on Northern Biodiversity, Université du Québec à Rimouski, G5L 3A1

$7 \quad{ }^{3}$ Centre d'Études Nordiques, Université du Québec à Rimouski, G5L 3A1

$8{ }^{4}$ Molecular Biology Unit, Fisheries and Oceans Canada, Moncton, NB, E1C 9B6

$9{ }^{5}$ Département de Biologie, Université de Moncton, E1A 3E9 Canada

$10 \quad{ }^{6}$ U.S. Fish and Wildlife Service, Migratory Bird Management, Anchorage, Alaska 99503 USA

$11{ }^{7}$ Québec Center for Biodiversity Science, Université du Québec à Rimouski, G5L 3A1

$12 *$ Corresponding author:

13 Marie-Andrée Giroux

14 Canada Research Chair in on Northern Biodiversity

15 Département de biologie

16 Université du Québec à Rimouski

17 G5L 3A1 Canada

18 Email: marie.a.giroux@gmail.com 


\section{Abstract}

21 Sex-role reversal, in which males care for offspring, can occur when mate competition is

22 stronger between females than males. Secondary sex traits and mate attracting displays in sex-

23 role-reversed species are usually more pronounced in females than in males. The red phalarope

24 (Phalaropus fulicarius) is a textbook example of a sex-role-reversed species. It is generally

25 agreed that males are responsible for all incubation and parental care duties, whereas females

26 typically desert males after having completed a clutch and may pair with new males to lay

27 additional clutches. The breeding plumage of female red phalaropes is usually more brightly

28 colored than male plumage, a reversed sexual dichromatism usually associated with sex-role

29 reversal. Here, we confirm with PCR-based sexing that male red phalaropes can exhibit both the

30 red body plumage typical of a female and the incubation behavior typical of a male. Our result,

31 combined with previous observations of brightly colored red phalaropes incubating nests at the

32 same arctic location (Igloolik Island, Nunavut, Canada), suggests that plumage dichromatism

33 alone may not be sufficient to distinguish males from females in this breeding population of red

34 phalaropes. This stresses the need for more systematic genetic sexing combined with

35 standardized description of intersexual differences in red phalarope plumages. Determining

36 whether such female-like plumage on males is a result of phenotypic plasticity or genetic

37 variation could contribute to further understanding sex-role reversal strategies in the short Arctic 38 summer. 
41 Sex-role reversal, in which males care for offspring, can occur when mate competition is

42 stronger between females than males (Gwynne 1991, Clutton-Brock and Vincent 1991,

43 Kvarnemo and Ahnesjo 1996). Biases in the intensity of mating competition can result from

44 differences in operational sex ratios (the ratio of males to females ready to mate), which can in

45 turn be associated with biases in potential reproductive rates (Emlen and Oring 1977, Kvarnemo

46 and Ahnesjo 1996). Theory predicts that, as a result of biases in the intensity of mating

47 competition, secondary sex traits and mate attracting displays in sex-role-reversed species will be

48 more pronounced in females than in males (Andersson 1994; Eens and Pinxten 2000; Trivers

49 1985).

The red phalarope (Phalaropus fulicarius) is a textbook example of a sex-role-reversed species (Alcock 2013). It is generally agreed that males are responsible for all incubation and parental care duties, whereas females typically desert males after having completed a clutch and may pair with new males to lay additional clutches (sequential polyandry; Dale et al. 1999;

Schamel and Tracy 1977). The mating system of the red phalarope has been described as female access polyandry, a system in which females do not defend resources, but rather limit access to males by converging at feeding areas to mate (Emlen and Oring 1977). The breeding plumage of female red phalaropes is usually more brightly colored than male plumage (Tracy et al. 2002;

Figure 1), a reversed sexual dichromatism usually associated with sex-role reversal (Heinsohn et al. 2005). It is also recognized that there is considerably more plumage variations among males, and that the most brightly colored males can approach female levels of coloration (Pyle 2008;

61 Tracy et al. 2002). However, mottled crowns have been identified as the characteristic that was 
62 most diagnostic of males (Tracy et al. 2002). Such overlap in the plumage of male and female

63 red phalaropes (Tracy et al. 2002) might explain why previous studies have reported incidental

64 observations of red phalaropes showing typical female plumage either incubating eggs ( 3 out of

6517 nests; Forbes et al. 1992) or brooding chicks (Sutton 1932).

66 Here, we describe the observation of a red phalarope exhibiting both the red body

67 plumage and the plain black crown of a female, but the incubation behavior typical of a male on

68 Igloolik Island (Nunavut, Canada), during summer 2014. Our objective was to genetically sex

69 this individual (hereafter referred to as the "ambiguous" individual) to determine whether it was

70 a brightly colored male or a female. We determined the sex of the ambiguous bird by using a

71 DNA marker universally used for sexing birds (Fridolfsson and Ellegren 1999), comparing the

72 band patterns of the ambiguous bird with those obtained with samples of red phalaropes sexed by

73 dissection.

\section{Methods}

\section{Study area}

76 We conducted fieldwork on Igloolik Island (Nunavut, Canada; $69^{\circ} 24^{\prime} \mathrm{N}, 81^{\circ} 32^{\prime} \mathrm{W}$ ) between early

77 June and early August in 2014 (Lecomte and Giroux 2015). This island is located in northwest

78 Foxe Basin next to the Melville Peninsula and south from the northern part of Baffin Island. The

79 study area is located in a mosaic of wet (sedge/grass moss wetland), mesic (non-tussock sedge,

80 dwarf-shrub, moss tundra), and dry (prostrate dwarf-shrub, herb tundra) habitat patches

81 interspersed by ponds and lakes. We identified habitats as per the Circumpolar Arctic Vegetation

82 map (CAVM-Team 2003).

\section{Nest monitoring}


84 We located red phalarope nests by following birds on incubation recesses back to their nests or

85 by flushing nests when walking or dragging a 30-m rope (9-mm-diameter). We searched for

86 nests intensively within a 36-ha nest plot and a 24-ha nest plot, and also recorded the presence of

87 nests found opportunistically outside of the nest plots. We recorded the location of each nest

88 using a Global Positioning System (Garmin eTrex), and placed three nest markers at 1-m, 5-m

89 and 10-m north of the nest to allow nest relocation. We monitored nests according to a 5-day

90 visitation schedule.

\section{Capture}

92 We captured the ambiguous individual using a bownet placed on its nest on 16 July 2014 (1 day

93 before hatching). We marked the bird with a metal band, a unique individual combination of

94 three colored darvic bands, and a unique site-specific combination of two colored bands. We

95 measured and recorded its bill length (exposed culmen) using a caliper $( \pm 0.1 \mathrm{~mm}$ precision),

96 wing length using a ruler $( \pm 1 \mathrm{~mm})$, and body mass using a hanging Pesola scale $( \pm 1 \mathrm{~g})$. We

97 collected blood $(25 \mu \mathrm{l})$ from the basilic vein using a small gauge (27.5) needle to puncture the

98 vein before drawing the blood into a capillary tube. Blood was preserved in $95 \%$ ethanol (1.5

$99 \mathrm{ml})$. Finally, we took photographs of the general appearance of the bird.

\section{Control individuals}

101 Red phalaropes were opportunistically collected after being found dead during the breeding

102 season at Barrow, Alaska in 2011 (male) and 2012 (female). We confirmed the sex of those

103 control carcasses by visual inspection of their reproductive systems. Samples of muscles were

104 collected during dissection, preserved in tissue preservation buffer (240.24g Urea, $100 \mathrm{ml} 1 \mathrm{M}$

105 Tris $\mathrm{HCl} \mathrm{pH} 8.0,11.69 \mathrm{~g} \mathrm{NaCl}, 3.72 \mathrm{~g}$ EDTA, $5 \mathrm{~g} \mathrm{~N}$-Lauroyl-sarcosine, $\mathrm{npH}_{2} \mathrm{O}$ to 1 Liter). We 
106 used these samples as known-sex positive controls for PCR-based sex determination of the

107 ambiguous individual.

\section{PCR-based sex determination}

109 Three birds were sexed using PCR-based methods: one control male, one control female, and the

110 ambiguous bird. A small piece of tissue (close to $1 \mathrm{~mm}^{3}$ ) of the control birds was washed with 50

$111 \mu \mathrm{l}$ sterile water and centrifuged for $3 \mathrm{~min}$ at 10,000 $\mathrm{rpm}$. Water was removed and the tissue

112 washed a second time to remove any remaining salts from the preservation buffer that could have

113 interfered with the PCR reaction. The tissue was then broken down using the point of a sterile tip

114 in $50 \mu \mathrm{l}$ of sterile water. Blood samples of the ambiguous bird were properly mixed and $50 \mu \mathrm{l}$

115 were transferred to a new tube and centrifuged for 3 min at 10,000 rpm. Ethanol was removed

116 and pelleted red blood cells were re-suspended in $50 \mu \mathrm{LEPC}$ water. The mixtures produced for

117 each bird were incubated for $20 \mathrm{~min}$ at $55^{\circ} \mathrm{C}$ with constant shaking and $5 \mu 1$ was directly used as

118 DNA template for the PCR reactions.

119 Sex determination was carried out according to Fridolfsson and Ellegren (1999), with

120 minor modifications. $25 \mu \mathrm{l}$ reactions contained 12.5 $\mu$ l Amresco Hot Start Taq Master Mix 2x

121 (Amresco LLC., Solon, Ohio, US), $0.5 \mu \mathrm{M}$ of each primer and $5 \mu$ l of the DNA template or of

122 sterile water (negative control). Sequences of the primers used were 2550F:5'-

123 GTTACTGATTCGTCTACGAGA-3' and 2718R: 5'-ATTGAAATGATCCAGTGCTTG-3'.

124 PCR conditions were as follows: $94^{\circ} \mathrm{C}$ for $1 \mathrm{~min}$ of initial denaturation, 35 cycles at $94^{\circ} \mathrm{C}$ for 30

$125 \mathrm{sec}, 50^{\circ} \mathrm{C}$ for $30 \mathrm{sec}$ and $72^{\circ} \mathrm{C}$ for $1 \mathrm{~min}$, followed by a final extension at $72^{\circ} \mathrm{C}$ for $5 \mathrm{~min}$. PCR

126 products were finally separated using $1.2 \%$ agarose gel electrophoresis with GelRed ${ }^{\mathrm{TM}}$ nucleic

127 acid stain (Biotium, Inc., Hayward, California, US). The sex of the ambiguous bird was 
128 determined by comparing PCR products against those amplified from the pattern displayed by

129 the control male and female.

\section{Permits}

131 The Université de Moncton Animal Care Committee (permit \#14-05) and Environment Canada

132 (Scientific permit to capture and band migratory birds, \#10872) approved capture techniques and

133 immobilization procedures. We carried out red phalarope collections in Alaska under federal and

134 state permits issued to R. Lanctot. The Department of Environment - Government of Nunavut

135 (permit \#WL-2014-039) and the Canadian Wildlife Service (permits \#NUN-SCI-14-04)

136 approved field research.

\section{Results}

\section{Nest density}

139 In summer 2014, the density of red phalarope nests on our study plots averaged $25 \mathrm{nests} / \mathrm{km}^{2}$

$140(\mathrm{SD}=11, n=12$ and 4 nests in the 36 and 24-ha plots, respectively). The ambiguous individual

141 incubated in a nest located approximately $0.6 \mathrm{~km}$ outside both nest plots.

\section{Nesting behavior}

143 The ambiguous individual (Figure 1) incubated four eggs in a nest found at the beginning of its

144 incubation by flushing the bird on 27 June 2014. We revisited the nest on 2 July, 7 July, and 12

145 July when we saw signs of hatching of the eggs. We then visited the nest every 1-2 days until

146 hatching on 17 July. We observed the brightly colored individual incubating its nest at every visit

147 except on 13 July when the nest was not being attended.

\section{Physical characteristics}


149 The ambiguous individual was observed walking with an apparent handicap and upon capture,

150 we noted that two digits of its right foot were missing second phalanges. Its bill and wing lengths

151 overlapped with values reported for male and female red phalaropes trapped in Igloolik in a prior

152 study (J. Dale in Tracy et al. 2002), while body mass was on average $7.9 \mathrm{~g}$ and $12.2 \mathrm{~g}$ lower than

153 those of males and females, respectively (Table 1). Plumage patterns indicated the ambiguous

154 bird had the red body feathers and plain black crown indicative of a female, but wing feathers

155 resembling male feathers (Fig. 1).

\section{PCR-based sex determination}

157 The male and female positive controls exhibited the expected discriminative band pattern. The

$158 \mathrm{~W}$-chromosome product amplified in the female was smaller than the Z-chromosome fragment

159 amplified in the male, with sizes of approximately $300 \mathrm{bp}$ and $550 \mathrm{bp}$, respectively (Figure 2).

160 The PCR product amplified from the ambiguous bird was identical to that of the control male,

161 namely with a single product of around 550 bp (Figure 2). No amplicon was observed in the

162 negative control (Figure 2).

\section{Discussion}

164 According to PCR-based sexing, the brightly colored, ambiguous red phalarope was a male. Our

165 result, combined with previous observations of brightly colored red phalarope males (Forbes et

166 al. 1992; Tracy et al. 2002), stresses the need for conducting more systematic genetic sexing

167 combined with a standardized description of red phalarope plumage. This is of particular

168 importance as the characteristic that is considered diagnostic of even bright males, namely the

169 mottled crown, was not observed in the male described in this study.

170 There are a variety of reasons why bright male plumage might occur in this species. 
171 Johns (1964) showed that an injection of testosterone could experimentally induce the red nuptial

172 feathers in phalaropes. Whether the bright plumage observed in the male red phalarope in our

173 study could be associated with testosterone remains to be determined. In addition, it is unknown

174 whether the physiological mechanism (testosterone or another mechanism) behind this feather

175 coloration is a result of phenotypic plasticity, genetic variation or both. Yet, observations of eight

176 males, including males from Igloolik Island (J. Dale, personal communication, 2016), whose

177 distinctive plumage coloration was maintained over successive breeding seasons suggest that

178 plumage coloration is genetically determined (Tracy et al. 2002). It is interesting that our

179 ambiguous male had cryptic wing feathers like his male counterparts (Figure 1); such wing

180 feather coloration would provide the necessary camouflage to avoid predation while incubating a

181 nest. Further studies are required to sex individuals displaying such wing coloration and other

182 potential distinguishing criteria between males and females currently discussed among shorebird

183 biologists but as yet unpublished (e.g. tawny stripes on the back). This is especially needed on

184 Igloolik Island as occasional observations conducted during summer 2015 in this location point

185 to the possibility that male feather coloration is highly variable (Lecomte \& Giroux, unpublish.

186 data), suggesting that our ambiguous male is not a singularity.

Redder males are thought to be of higher quality in species characterized by typical sex roles such as the bar-tailed godwit Limosa lapponica (Piersma and Jukema 1993). Yet, determining whether a female-like coloration would be associated with any variations in

190 reproductive traits for males remains to be studied in the red phalarope (see an equivalent study

191 in ruffs Philomachus pugnax: Küpper et al. 2016). To better understand the mechanisms

192 inducing bright feather coloration in males, further studies are needed to compare physiological 193 parameters and hormonal levels in bright individuals compared to typical bright females and dull 
194 males, and mate selection and breeding success of variously patterned males.

The PCR method used to sex these three individuals is based on the detection of a

196 difference of intron size in similar copies of a gene found on the $\mathrm{W}$ and $\mathrm{Z}$ sex chromosomes

197 (CHD1W and CHD1Z, respectively). This method proved to be successful for sex discrimination

198 of most of the non-ratite bird species assayed by Fridolfsson and Ellengren (1999). When

199 successful amplification occurs, a single PCR product is amplified in males, characteristic of

200 their ZZ sexual chromosomes. For females, that have ZW sex chromosomes, two PCR products

201 are usually amplified, with the largest product corresponding to the Z-chromosome, as in males.

202 Females can sometimes display a single band pattern, when the W chromosome is preferentially

203 amplified over the $\mathrm{Z}$ chromosome. In these cases, the single female product band is smaller than

204 the single male product, still allowing the robust discrimination of both sexes (Fridolfsson and

205 Ellegren 1999). Dawson et al. (2001), however, reported some exceptions in which this method

206 did not result in amplification products of different sizes, highlighting the importance of using

207 positive controls of both sexes to validate the assay. In our study, the pattern exhibited by the

208 control female was not unexpected and allowed differentiation of males from females. We

209 repeated DNA amplification of the ambiguous individual using the same set of primers, and it

210 resulted in the same $550 \mathrm{bp}$ band (data not shown). We are thus confident of the sexual

211 assignment of our ambiguous bird as a male.

212 Our result indicates that in some situations plumage dichromatism alone may not be

213 sufficient to distinguish red phalarope males from females. Identifying diagnostic plumage

214 characteristics of males would require range-wide studies scoring plumage of genetically sexed

215 individuals with standardized protocols (Reynolds 1987; Troscianko and Stevens 2015). We also 
216 recommend further work to determine whether such female-like plumage on males are a result of

217 phenotypic plasticity or genetic variation, and whether brightly colored males derive

218 reproductive benefits from their coloration.

\section{Acknowledgments}

220 We thank M.-C. Frenette and M. Trottier-Paquet for their valuable assistance in the field, the

221 Government of Nunavut for their logistical support, D. Edwards for sharing his thoughts about

222 our observation, as well as four anonymous reviewers, W. Goymann, J. Dale, and G. Rebstock

223 that commented on a previous version of the manuscript. K. Sage and S. Talbot from the U. S.

224 Geological Service, Alaska Science Center provided samples from archived red phalaropes. The

225 findings and conclusions in this article are those of the authors and do not necessarily represent

226 the views of the US Fish and Wildlife Service. 


\section{References}

228 Alcock J (2013) Animal Behavior: An evolutionary approach. Sinauer Associates, Sundreland, $229 \quad$ MA.

230 Andersson M (1994) Sexual selection. Princeton University Press, Princeton, NJ

231 CAVM-Team (2003) Circumpolar Arctic Vegetation Map. (1:7,500,000 scale). US Fish and

232 Wildlife Service, Anchorage, Alaska

233 Clutton-Brock TH, Vincent AJC (1991) Sexual selection and the potential reproductive rates of 234 males and females Nature 351: 58-60 doi:10.1038/351058a0

235 Dale J, Montgomerie R, Michaud D, Boag P (1999) Frequency and timing of extrapair 236 fertilisation in the polyandrous red phalarope (Phalaropus fulicarius) Behav Ecol Sociobiol 46:50-56 doi:10.1007/s002650050591

Dawson D, Darby S, Hunter F, Krupa A, Jones I and Burke T (2001) A critique of avian CHDbased molecular sexing protocols illustrated by a Z-chromosome polymorphism detected in auklets. Mol Ecol Notes 1:201-2014 doi:http://dx.doi.org/10.1046/j.14718278.2001.00060.x

242 Eens M, Pinxten R (2000) Sex-role reversal in vertebrates: behavioural and endocrinological accounts Behav Processes 51:135-147 doi:http://dx.doi.org/10.1016/S03766357(00)00124-8

Emlen S, Oring L (1977) Ecology, sexual selection, and the evolution of mating systems Science 197:215-223 doi:10.1126/science.327542

247 Forbes G, Robertson K, Ogilvie C, Seddon L (1992) Breeding Densities, Biogeography, and 248 Nest Depredation of Birds on Igloolik Island, N.W.T Arctic 45:295-303 doi:10.2307/40511461 
250 Fridolfsson A-K, Ellegren H (1999) A Simple and Universal Method for Molecular Sexing of $251 \quad$ Non-Ratite Birds J Avian Biol 30:116-121 doi:10.2307/3677252

252 Gwynne, D. T. (1991). Sexual competition among females: What causes courtship-role reversal? 253 Trends Ecol Evol, 6: 118-121.

254 Heinsohn R, Legge S, Endler JA (2005) Extreme Reversed Sexual Dichromatism in a Bird 255 Without Sex Role Reversal Science 309:617-619 doi:10.1126/science.1112774 256 Johns JE (1964) Testosterone-Induced Nuptial Feathers in Phalaropes The Condor 66:449-455 257 doi:10.2307/1365222

258 Küpper C, Stocks M, Risse JE, Remedios ND, Farrell LL, McRae SB, Morgan TC, Karlionova 259 N, Pinchuk P, Verkuil YI, Kitaysky AS, Wingfield JC, Piersma T, Zeng K, Slate J, 260 Blaxter M, Lank DB, Burke TB (2016) A supergene determines highly divergent male 261 reproductive morphs in the ruff Nat Genet 48:79-83 doi:10.1038/ng.3443

262 http://www.nature.com/ng/journal/v48/n1/abs/ng.3443.html - supplementary-information 263 Kvarnemo C, Ahnesjo I (1996) The dynamics of operational sex ratios and competition for mates 264 Trends Ecol Evol 11:404-408 doi:http://dx.doi.org/10.1016/0169-5347(96)10056-2

265 Lecomte N, Giroux M-A (2015) New avian breeding records for Igloolik, Nunavut Can Field$266 \quad$ Nat 129:194-196

267 Piersma T, Jukema J (1993) Red Breasts as Honest Signals of Migratory Quality in a Long268 Distance Migrant, the Bar-Tailed Godwit The Condor 95:163-177 doi:10.2307/1369398

269 Pyle P (2008) Identification Guide to North American Birds. Part II: Anatidae to Alcidae. Slate 270 Creek Press, USA, 
271 Reynolds JD (1987) Mating system and nesting biology of the Red-necked Phalarope Phalaropus

272 lobatus: what constrains polyandry? Ibis 129:225-242 doi:10.1111/j.1474-

273 919X.1987.tb03203.x

274 Schamel D, Tracy D (1977) Polyandry, replacement clutches, and site tenacity in the red

275 phalarope (Phalaropus fulicarius) at Barrow, Alaska Bird-Banding 48:314-324

276 doi: $10.2307 / 20699123$

277 Sutton GM. 1932. The birds of Southampton Island. Memoirs of the Carnegie Museum. Vol. 12. $278 \quad 275$ pages.

279 Tracy DM, Schamel D, Dale J (2002) Red Phalarope (Phalaropus fulicarius). Ithaca: Cornell Lab 280 of Ornithology. Retrieved from the Birds of North America Online:

$281 \quad$ http://bna.birds.cornell.edu/bna/species/698.

282 Trivers RL (1985) Social evolution. The Benjamin Cummings Publishing Company, Menlo 283 Park, California

284 Troscianko J, Stevens M (2015) Image calibration and analysis toolbox - a free software suite 285 for objectively measuring reflectance, colour and pattern Methods in Ecology and 286 Evolution:n/a-n/a doi:10.1111/2041-210X.12439 
289 Table 1. Morphometric measurements $( \pm \mathrm{SD})$ of red phalaropes captured in Igloolik in a previous

290 study (Tracy et al. 2002) compared to those of the ambiguous individual measured in 2014.

291 Sample sizes are within brackets.

\section{Previous study Ambiguous individual}

\section{Bill length (mm)}

Male

$22.2 \pm 1.5(48)$

Female

$22.7 \pm 1.2(14)$

23.5

\section{Wing length (mm)}

Male

$128.4 \pm 2.3(48)$

Female

$134.9 \pm 2.9(14)$

Body mass (g)

Male

$52.9 \pm 3.8(45)$

Female

$57.2 \pm 4.7(13)$ 


\section{Figure captions}

295 Fig. 1. Comparison between the breeding plumage of three red phalaropes: 1) a typical male, 2)

296 the ambiguous bird (brightly colored individual incubating), and 3) a typical female. All pictures

297 were taken in Igloolik, Nunavut, Canada. Photos: N. Lecomte.

298 Fig. 2. PCR sex determination for red phalaropes at Igloolik, Nunavut, Canada and Barrow, 299 Alaska. PCR products were separated with agarose gel electrophoresis and stained with

300 GelRed $^{\mathrm{TM}}$ nucleic acid (Biotium, Inc., Hayward, California, US; see methods) using sexing

301 primers specific to birds (2550F /2718R; Fridolfsson \& Ellegren 1999). M=molecular marker,

302 1=typical male sampled in Barrow (550bp), 2=the ambiguous bird (550bp), 3=typical female 303 sampled in Barrow (300bp), and 4=negative control. 


\section{Figure 1}

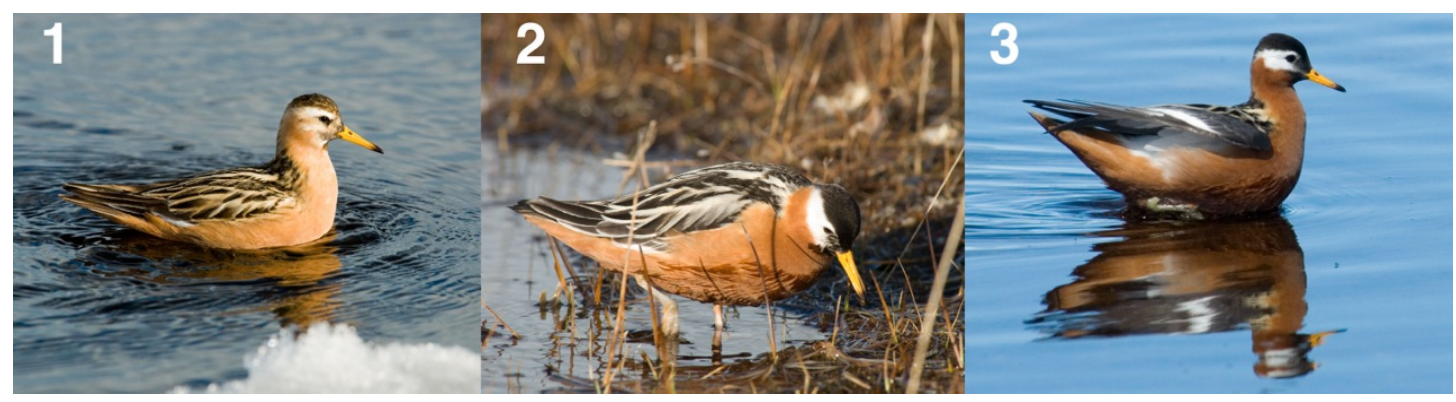




\section{Figure 2}

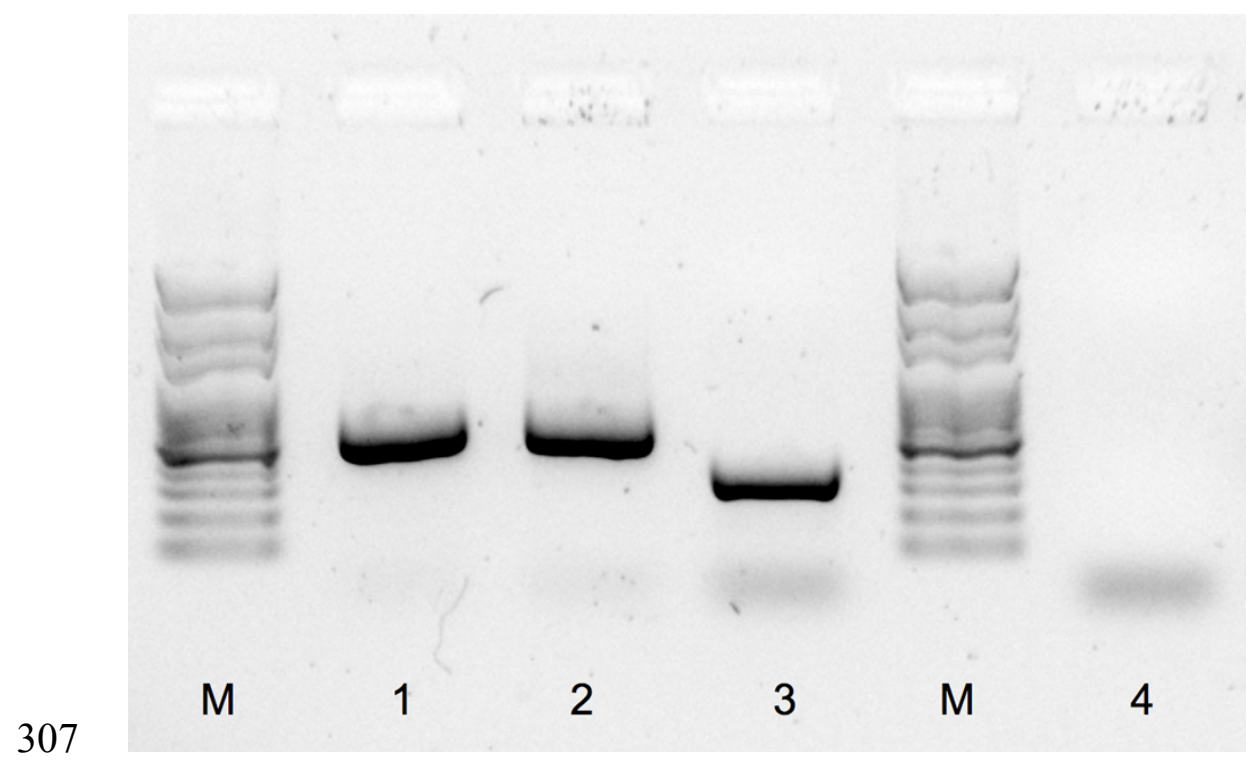

